R. Djanashvili and S. Barjadze - A new species of the genus Plutomurus Yosii, 1956 (Collembola, Tomoceridae) from Georgian caves. Journal of Cave and Karst Studies, v. 73, no. 1, p. 28-30. DOI: 10.4311/jcks20101sc0147

\title{
A NEW SPECIES OF THE GENUS PLUTOMURUS YOSII, 1956 (COLLEMBOLA, TOMOCERIDAE) FROM GEORGIAN CAVES
}

\author{
Revaz Duanashvili and Shalva Barjadze \\ Entomology and Biocontrol Research Centre, Ilia State University, Chavchavadze av.31,0179, Tbilisi, Georgia, shalva1980@yahoo.com
}

\begin{abstract}
A new species, Plutomurus birsteini sp. n., from Georgian caves is described and illustrated. It is similar to Plutomurus baschkiricus (Skorikow, 1899). Differences between the species are discussed. A key to the genus Plutomurus species found in the Caucasus is provided.
\end{abstract}

\section{INTRODUCTION}

The genus Plutomurus Yosii, 1956 is represented by twenty-three species worldwide (Kniss and Thibaud, 1999; Bellinger et al., 1996-2010). The species belonging to this genus are distributed in North America, Europe, and Asia and live in caves or soils (Yosii, 1956, 1966, 1967, 1991; Chrisitiansen, 1964, 1980; Gruia, 1965; Martynova, 1969, 1977; Rusek and Weiner, 1977; Kniss and Thibaud, 1999).

Before now, four species, Plutomurus abchasicus Martynova, 1969 (Georgia, in soils), P. jeleznovodski Kniss and Thibaud, 1999 (north Caucasus, in cave), P. kelasuricus Martynova, 1969 (north and south Caucasus, in caves) and P. sorosi Kniss and Thibaud, 1999 (north Caucasus, in cave) have been recorded in the Caucasus (Martynova, 1969; Kniss and Thibaud, 1999; Barjadze and Djanashvili, 2008).

Re-examination of the springtails collected by Dr. R. Djanashvili in Georgian caves during 1966-1970 led us to describe here a new species.

\section{Diagnosis of the Genus Plutomurus Yossi, 1956}

Eyes from $6+6$ to $0+0$. Prelabial setae from $2+2$ to 4 +4 . This genus is easily distinguished by the presence of large spine-like setae at the external bases of the dens combined with a well developed multisetaceous trochateral organs on the trochanter and on the base of the femur. There are four or fewer intermediate teeth on the mucro, and there is only a single small mucronal lamella, usually on the basal tooth. Most have some pigment, but eyes are often reduced. Sexual dimorphism absent. The genus is Holarctic but does not occur in arctic regions. It often is found in alpine areas. Within the Holarctic region, they are limited to eastern Asia, western Europe, the Caucasian region, and western North America. Although 60\% are found in caves and many of these have not been found elsewhere, they show very little troglomorphy.

\section{Material Examined}

Holotype O’ from Sakishore Cave, 06.VII.1969, leg. R. Djanashvili and 21 paratypes are on the slides. Specimens from the same locality are mounted on the same slide. Paratypes: three specimens, Chuneshi Cave, 21.IX.1968, leg. R. Djanashvili; one specimen, Sataplia IV Cave, 10.X.1966, leg. R. Djanashvili; one specimen, Tvishi Cave, 12.IX.1968, leg. R. Djanashvili; one specimen, Magara Cave, 18.VIII.1967, leg. R. Djanashvili; three specimens, Tsakhi Cave, 31.VIII.1966, leg. R. Djanashvili; one specimen, Sharaula II Cave, 20.VII.1970, leg. R. Djanashvili; four specimens, Nikortsminda Cave, 03.VII.1969, leg. R. Djanashvili; one specimen, Sakishore Cave, 06.VII.1969, leg. R. Djanashvili; two specimens, Bnelaklde Cave, 18.IX.1967, leg. R. Djanashvili; one specimen, Taroklde Cave, 15.IX.1967, leg. R. Djanashvili; three specimens, Khvedelidze Cave, 29.VI.1969., leg. R. Djanashvili. Holotype and paratypes are deposited in the Entomology and Biocontrol Research Centre of Ilia State University, Tbilisi, Georgia.

\section{Description of Plutomurus birsteini Duanashyili AND BARJADZE SP. N.}

Body length 1.0 to $3.3 \mathrm{~mm}$. Body light yellowish-gray; anterior part of head and III and IV antennal segments a little darker. Antenna c. 1.5 times shorter than body. Eye patch small, black with 6 eyes (Fig. 1 A). Prelabial setae $2+2$, labrum with 5, 5, 4 setae and 4 curved setae on the distal part of labrum. Trochanteral organ well developed on trochanter and femur, composed of large number of short setae (more than 40) and several long setae. All parts of ventral tube with many setae. Spine-like setae on tibiotarsus I, II, and III: 0,0 , 1 . Tenent hairs weakly to moderately clavate. Ratio of unguis, unguiculus, and tenent hair in holotype 16:9:11. Unguis with well developed pseudonychia, 0.38 to 0.56 times as long as inner part of unguis. Unguis of prolegs with 2 to 4 inner teeth. Unguis of meso and metalegs with 2 to 3 inner teeth (Fig. 1 B). Unguiculus of all legs always without inner teeth. Tenaculum with $4+4$ teeth and 1 heavy seta on corpus (Fig. 1 C). Ratio of manubrium/dens/mucro in holotype 6.3:9.8:1. Ventral side of manubrium with numerous relatively thick and large setae. Outer margins of dens with 4 thick and large spine-like setae. Mucro with 2 basal 


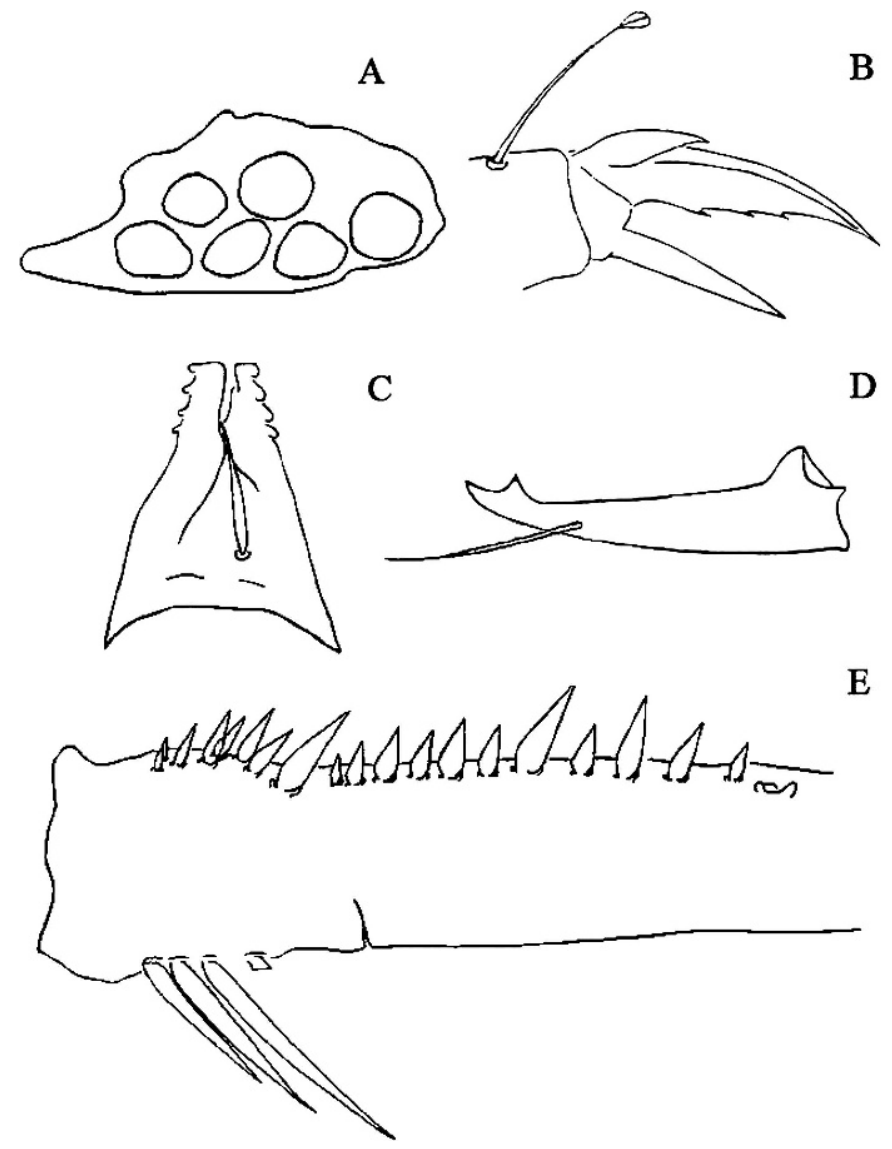

Figure 1. Plutomurus birsteini sp. n.: (A) eye patch; (B) claw III; (C) tenaculum; (D) mucro; (E) dens. denticles, without subapical denticles and 1 seta projecting prominently beyond apex (Fig. 1 D). Dental formula variable: $5-15$ 1-2 / 2-9 1 0-3 $0-1$ 0-3 0-1 0-3 0-1 $0-2$ 0-1 0 2 0-1 (Fig. 1 E).

\section{ETYMOLOGY}

The specific name is chosen in honor of the Russian biospeleologist Dr. J.A. Birstein, who was a supervisor of the first author.

\section{Discussion}

The lack of troglomorphic modifications makes it likely that this is a troglophile species and will be found outside of caves. This species is a very similar to Plutomurus baschkiricus, which differs from $P$. birsteini by: 1. Larger number of setae on the trochanteral organ (more than 40 short setae) and several long setae in P. birsteini, while there are 18 to 40 short setae and 2 to 4 large ones in $P$. baschkiricus; 2. Spine-like setae on tibiotarsus I, II, and III are $0,0,1$ in P. birsteini, while 0, 0, 2 in P. baschkiricus; 3 . Unguiculus of all legs always without minute inner teeth in $P$. birsteini, while 2 to 3 inner teeth are on each unguiculus of $P$. baschkiricus; 4. Dental formula: 5-15 1-2 / 2-9 1 0-3 01 0-3 0-1 0-3 0-1 0-2 0-1 0-2 0-1 in P. birsteini, while 6-8 1 I 9-13 1 in P. baschkiricus. A key to the genus Plutomurus Yosii, 1956 species distributed in the Caucasus is provided in Table 1.

\section{ACKNOWLEDGEMENTS}

We would like to thank to Dr. Kenneth A. Christiansen, Grinnell College, USA, for the valuable comments on the species description.

Table 1. A key to the genus Plutomurus Yosii, 1956 species distributed in the Caucasus.

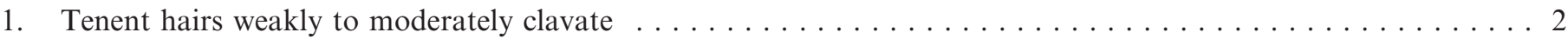

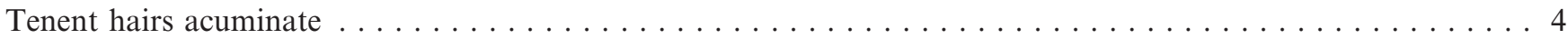

2. Eye patch always with 6 eyes. Mucro without subapical small denticles $\ldots \ldots \ldots \ldots \ldots \ldots \ldots \ldots$

Eye patch with 4 or 5 eyes. Mucro with 3 subapical denticles . . . . . . . . . P. sorosi Kniss and Thibaud, 1999

3. Trochanteral organ with more than 40 setae. Unguiculus of all legs always without minute inner teeth. Dental

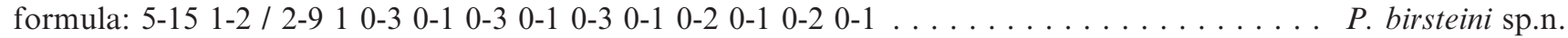
Trochanteral organ with less than 40 setae. Unguiculus of all legs always with a few minute inner teeth. Dental

formula: $4-51 / 6131 \ldots \ldots \ldots \ldots \ldots$. jeleznovozski Kniss and Thibaud, 1999

4. Spine-like setae on tibiotarsus I, II, and III 0, 0, 1. Prelabial setae 3+3 . . . . . . P. kelasuricus Martynova, 1969

Spine-like setae on tibiotarsus I, II, and III 0, 0, 2. Prelabial setae 2+2 . . . . . . P. abchasicus Martynova, 1969 


\section{REFERENCES}

Barjadze, Sh., and Djanashvili, R., 2008, Checklist of the springtails (Colembola) of Georgia: Caucasian Entomological Bulletin, v. 4, no. 2, p. 187-193.

Bellinger, P.F., Christiansen, K.A., and Janssens, F., 1996-2010, Checklist of the Collembola of the World. http://collembola.org [accessed April 27, 2010]

Christiansen, K., 1964, A revision of the nearctic members of the genus Tomocerus: Revue d'Écologie et de Biologie du Sol, v. 1, p. 639678.

Christiansen, K., 1980, A new nearctic species of the genus Tomocerus (Collembola: Entomobryidae): Proceedings of the Iowa Academy of Sciences, v. 87, p. 121-123.

Gruia, M., 1965, Contributii la studiul collembolelor din România: Lucrarile Institutului de Speologie "Emil Rakovita", v. 4, p. 191-202.

Kniss, V., and Thibaud, J., 1999, Le genre Plutomurus en Russie et en Georgie (Collembola, Tomoceridae): Revue française d' Entomologie (N.S.), v. 21, no. 2, 57_64 p.
Martynova, E., 1969, Springtails of the family Tomoceridae (Collembola) from the fauna of the USSR: Entomological Review, v. 43, p. 299-314 (in Russian).

Martynova, E., 1977, Springtails of the family Tomoceridae (Collembola) from the fauna of the Far East: Insect Fauna of the Far East, v. 46, no. 149, p. 3-16 (in Russian).

Rusek, J., and Weiner, W.M., 1977, Plutomurus carpaticus sp. n. (Collembola: Tomoceridae) from the Carpathian Mountains: Bulletin de l'Académie Polonaise des Sciences, v. 25, p. 741-747.

Yosii, R., 1956, Monographie zur Höhlencollembolen Japans: Contribution from the Biological Laboratory Kyoto University 3, 109 p.

Yosii, R., 1966, Results of the speleological survey of South Korea 1966, IV cave Collembola: Bulletin of the National Science Museum Tokyo, v. 9 , p. $541-561$.

Yosii, R., 1967, Studies on the collembolan family Tomoceridae with special reference to Japanese forms: Contribution from the Biological Laboratory Kyoto University 20, $54 \mathrm{p}$.

Yosii, R., 1991, A new species of Tomocerid Collembola from the cave of the Pref. Iwata: Annals of the Speleological Research Institute of Japan, v. 9, p. 1-2. 